\title{
Identification of Human Immunodeficiency Virus (HIV) Envelope Type-Specific T Helper Cells in an HIV-infected Individual
}

\author{
Christopher M. Walker," Kathlyn S. Steimer, ${ }^{\ddagger}$ Kenneth L. Rosenthal, ${ }^{\mathbf{5}}$ and Jay A. Levy ${ }^{*}$ \\ ${ }^{*}$ Cancer Research Institute, University of California, School of Medicine, San Francisco, California, 94143; ${ }^{\ddagger}$ Chiron Research \\ Laboratories, Chiron Corporation, Emeryville, California, 94608; and ${ }^{\S}$ Department of Pathology, McMaster University \\ Health Sciences Centre, Hamilton, Ontario L8N 3Z5, Canada
}

\begin{abstract}
Two T helper cell clones recognizing the gp 120 envelope protein of HIV were generated from the peripheral blood of a healthy seropositive individual. These cells were type specific as they proliferated and produced IL 2 when stimulated by an epitope in the amino-terminal half of $\mathrm{gp} 120$ of $\mathrm{HIV}_{\mathrm{SF2}}$, but not by a similar region of $\mathrm{HIV}_{\mathrm{Zr6}}$, a Zairian HIV-1 isolate. These two viruses differ by $26 \%$ in the deduced amino sequence of the gp 120 protein. Moreover, the antigenic site(s) recognized by the cloned $T$ cells are distinct from those recognized by envelope-specific antibodies. These observations have important implications for the development and use of anti-HIV vaccines.
\end{abstract}

\section{Introduction}

The major external glycoprotein (gp 120) of the HIV is recognized by both neutralizing antibodies (1) and cytotoxic T lymphocytes $(2,3)$ and, thus, is a prime candidate for use in vaccines against AIDS. Individual isolates of HIV display considerable genetic diversity within the region coding for this protein (4). Sequence polymorphisms are clustered in a limited number of variable domains that are flanked by conserved regions (5). Potential antigenic sites that can be recognized by $T$ lymphocytes are present in both regions when the hydrophobicity and predicted secondary structure of the protein are considered (6). Antiviral $\mathrm{T}$ lymphocytes are able to recognize either conserved or variable antigenic sites on viruses such as influenza (7) and herpes simplex virus (8), but similar patterns of reactivity by human T cells against HIV have not yet been demonstrated. We report here the generation of clonal HIVspecific $\mathrm{T}$ helper cell lines, derived from PBMC of a healthy HIV seropositive individual. These cells proliferated and produced IL 2 when stimulated by type-specific epitopes on the gp 120 envelope protein.

Address reprint requests to Dr. Jay A. Levy, Cancer Research Institute Box 0128, School of Medicine, University of California, San Francisco, CA 94143.

Received for publication 18 July 1988 and in revised form 14 September 1988.

J. Clin. Invest.

(C) The American Society for Clinical Investigation, Inc.

$0021-9738 / 88 / 12 / 2172 / 04 \quad \$ 2.00$

Volume 82, December 1988, 2172-2175

\section{Methods}

Recombinant HIV gp 120 antigens. Recombinant gp 120 envelope antigens from $\mathrm{HIV}_{\mathrm{SF}_{2}}$ and $\mathrm{HIV}_{\mathrm{Zr} 6}$ (provided by Dr. P. Barr, Chiron Research Laboratories, Emeryville, CA) were produced in the yeast, Sacchromyces cerevisiae, using intracellular expression vectors similar to those described previously (9). These vectors yield products that are not glycosylated. All of these antigens were insoluble when produced intracellularly in yeast. The recombinant antigens were purified from the insoluble fraction of yeast lysates as described previously for other recombinant HIV-1 envelope polypeptides (9). Fig. 1 shows the amino acid coordinates of the $\mathrm{HIV}_{\mathrm{SF} 2}(10)$ or $\mathrm{HIV}_{\mathrm{Zr}}$ (11) envelope gene products represented by each recombinant polypeptide. The putative signal peptides of $\mathrm{HIV}_{\mathrm{SF} 2}$ and $\mathrm{HIV}_{\mathrm{Zr} 6}$ gp 120 end at amino acid $29(9$, 11). The COOH-terminal amino acid of $\mathrm{HIV}_{\mathrm{SF} 2} \mathrm{gp} 120$ is at 509 (9) and $\mathrm{HIV}_{\mathrm{Zr} 6} \mathrm{gp} 120$ is at 510 (11). Recombinant core $\mathrm{p} 25$ protein (gag) of $\mathrm{HIV}_{\mathrm{SF} 2}$ was expressed in an Escherichia coli vector (12).

Generation of cloned HIV-specific T cell lines. PBMC $\left(1 \times 10^{7}\right)$ from a healthy, HIV seropositive subject were suspended in $1 \mathrm{ml}$ of RPMI culture medium containing $10 \mu \mathrm{g}$ of $\mathrm{HIV}_{\mathrm{SF} 2}$ env 2-3 peptide, 2.5\% IL 2 (Electro-Nucleonics, Inc., Silver Spring, MD), 10\% human AB serum (Irvine Scientific, Santa Ana, CA), 2 mM L-glutamine, and antibiotics. Cells were cultured in 24-well tissue culture dishes for $7 \mathrm{~d}$ at $37^{\circ} \mathrm{C}$ in a $5 \% \mathrm{CO}_{2}$ incubator, and then readjusted to $5 \times 10^{6} / \mathrm{ml}$ in medium containing $10 \mu \mathrm{g} / \mathrm{ml}$ env $2-3$ and $2.5 \%$ IL 2 . After an additional $7 \mathrm{~d}$ of incubation, the cells were seeded at a concentration of 1 cell/well into 60-well Terasaki plates (Robbins Scientific, Mountain View, CA), along with $1 \times 10^{4}$ irradiated $(2,000 \mathrm{R})$ autologous PBMC, in $0.015 \mathrm{ml}$ of culture medium containing $10 \mu \mathrm{g} / \mathrm{ml} \mathrm{HIV}_{\mathrm{SF}_{2}}$ env 2-3 antigen and $5 \%$ IL 2 . After expansion, T cells $\left(5 \times 10^{2}\right)$ were restimulated in $16-\mathrm{mm}$ wells at weekly intervals with $2 \times 10^{5}$ irradiated (12,000 R) TM-B cells (as a source of antigen-presenting cells) in culture medium supplemented with $5 \%$ IL 2 and $10 \mu \mathrm{g} / \mathrm{ml}$ env 2-3 antigen. TM-B is a transformed cell line established by infecting the subject's peripheral blood $B$ cells with cell-free supernatant from the EBV-transformed marmoset cell line B95-6 as described (13).

Proliferation assay. The proliferative response of the $\mathrm{T}$ cell clones to the test antigens were measured by incubating $5 \times 10^{4}$ responder cells with an equal number of irradiated TM-B cells for $3 \mathrm{~d}$ in the presence of 5\% IL 2, and test antigen at the indicated concentrations. Wells were harvested onto glass filter discs using an automatic harvesting device and the amount of $\left[{ }^{3} \mathrm{H}\right]$ thymidine incorporated was determined by liquid scintillation counting.

IL 2 assay. Culture supernatants were assayed for their ability to induce proliferation of the IL 2-dependent cell line $\mathrm{H}-\mathrm{Y}$ as previously described (14).

Antibody ELISA assay. Human sera were assayed for antibodies to each recombinant antigen in an ELISA assay as described (15), with the following modifications: recombinant antigens were diluted to 2 $\mu \mathrm{g} / \mathrm{ml}$ in $0.05 \mathrm{M}$ sodium borate $(\mathrm{pH} \mathrm{9.0)}$ and $100 \mu \mathrm{l} /$ well was adsorbed to microtiter plates for $12-18 \mathrm{~h}$ at $4^{\circ} \mathrm{C}$. Sera were diluted 1:100 in 0.1 $\mathrm{M}$ phosphate buffer ( $\mathrm{pH}$ 7.4) containing $0.5 \mathrm{M} \mathrm{NaCl}, 0.1 \%$ casein, and 


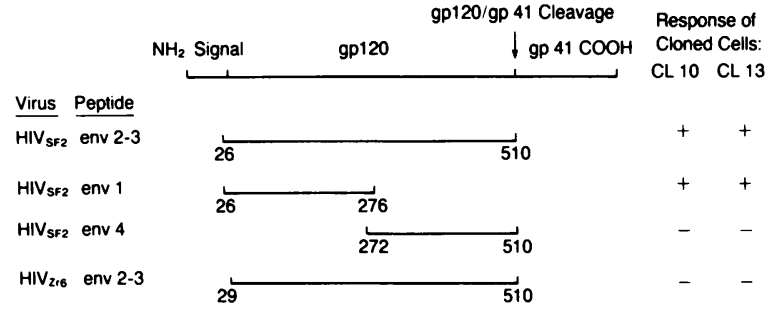

Figure 1. Location of recombinant polypeptides within the envelope glycoprotein sequence of $\mathrm{HIV}_{\mathrm{SF} 2}$ and $\mathrm{HIV}_{\mathrm{Zr6}}$. The amino acid residues that mark the amino and carboxy terminus of each peptide are indicated. The results of proliferative responses by the two clones induced by the recombinant antigens are summarized at the right of the figure.

$100 \mu \mathrm{g} / \mathrm{ml}$ of an extract from yeast (Red Star). This material was included to adsorb antibodies to yeast proteins that might react with minor contaminants in the purified recombinant antigen preparations. Horseradish peroxidase-conjugated goat antiserum to human immunoglobulin was used as the second-stage antibody. Sera were considered positive when the OD reading was 2.5 times that of the seronegative control.

\section{Results and Discussion}

For these studies, PBMC from an asymptomatic, HIV seropositive individual were incubated in vitro for $7 \mathrm{~d}$ with IL 2 and env 2-3, derived from $\mathrm{HIV}_{\mathrm{SF} 2}$ (Fig. 1). After a second incubation for 1 wk with IL 2 and the env 2-3 peptide, responding cells were seeded into 240 wells of Terasaki tissue culture dishes at a concentration of one cell per well for cloning. A total of 20 wells contained responder cells that could be further expanded by stimulation with env $2-3$. After subcloning, two stable T cell clones (CL 10 and CL 13) were established. They displayed a strong proliferative response to the env 2-3 antigen, and did not react with a protein extract from Saccharomyces cerevisiae (Table I) (9).

An analysis of the surface phenotype of the cloned cells using a fluorescence-activated cell analyzer revealed that they were $\mathrm{T}$ helper cells that expressed the CD3 and CD4 cell surface markers. Neither clone displayed the Leu 8 surface antigen, a marker that is expressed on $\mathrm{T}$ helper cells that induce suppressor cell activity (16). We verified that the CD4 $+T$ cell clones were not infected by HIV by finding no viral-associated reverse transcriptase in their culture supernatant or viral proteins in the cloned cells. Moreover, the cells were very sensitive to infection by isolates of HIV (10).

The antigen specificity of the clones was tested by using a panel of recombinant polypeptides representing different regions of the gp 120 protein from either $\mathrm{HIV}_{\mathrm{SF} 2}$ (9) or $\mathrm{HIV}_{\mathrm{Zr}}$, a Zairian isolate (Fig. 1, Table I). The amino acids coded for by the gp 120 gene from each of these two viruses differ by 26\% (Steimer, K., unpublished data). Proliferation of both clones was induced by the env 2-3 and env 1, but not the env 4 polypeptide of $\mathrm{HIV}_{\mathrm{SF}_{2}}$ (Table I). This observation indicated that the cells recognized an epitope in the amino-terminal half of the gp 120 molecule. The internal core p25 protein (gag) of HIV $_{\text {SF2 }}$ was also not recognized. Neither clone reacted with the env 2-3 or env 4 peptides of $\mathrm{HIV}_{\mathrm{Zr} 6}$ (Table I). It is unlikely that this unresponsiveness is caused by a lack of antigenicity of these proteins, as sera from African AIDS patients reacted with these peptides in an ELISA assay (see below, Table II). Rather, the observation indicated that the response of the cloned $\mathrm{T}$ cells was type specific. Clones CL 10 and CL 13 did not proliferate in the presence of env 2-3 when EBV-transformed B cells from another HIV seropositive individual were used as antigen-presenting cells (Table I). This individual did not share class II (HLA DR, DP, DQ) HLA antigens with the donor from whom the $\mathrm{T}$ cell clones were generated (data not shown). This result probably reflects a requirement for recognition of both viral (i.e., env 2-3) and self class II HLA antigens by the CD4+ $\mathrm{T}$ cells for activation to occur (17).

Activated CD4+ T cells produce IL 2 that is required for the proliferation of helper and cytotoxic $T$ lymphocytes (18), as well as B lymphocytes (19), during the generation of immune responses. Accordingly, we tested the ability of clone CL 10 to produce and use IL 2 after stimulation with recombinant gp 120 peptides. Cloned cells proliferated in IL 2-free medium when stimulated with env 2-3 and env 1 peptides of $\mathrm{HIV}_{\mathrm{SF} 2}$, but not env 4 or gag (Table III). Furthermore, only supernatants from those cultures in which proliferation was detected contained IL 2 (Table III). Many IL 2-producing human CD4+ T cell lines have the ability to mediate class II HLA-restricted virus-specific cytotoxic activity $(7,8)$. More recently, cloned CD4+ cells established from the peripheral blood of chimpanzees infected with recombinant vaccinia viruses that express HIV envelope glycoproteins have been shown to mediate HIV-specific cytotoxic activity (20). We tested the ability of

Table I. Proliferation of T Cell Clones in Response to Envelope gp 120 Polypeptides

\begin{tabular}{lclcrrr}
\hline Virus & Stimulator cells & Antigen & CL 10 & SI & CL 13 & SI \\
\hline None & TM-B & None & 1,198 & - & 3,456 & - \\
HIV $_{\text {SF2 }}$ & TM-B & env 2-3 & 27,532 & 23.0 & 21,482 & 6.2 \\
HIV $_{\text {SF2 }}$ & TM-B & env 1 & 26,754 & 22.3 & 16,498 & 4.8 \\
HIV $_{\text {SF2 }}$ & TM-B & env 4 & 966 & 0.8 & 3,346 & 1.0 \\
HIV $_{\text {SF2 }}$ & TM-B & gag & 1,490 & ND & 3,156 & 0.9 \\
HIV $_{\text {SF2 }}$ & WG-B & env 2-3 & ND & 0.6 & 3,276 & 0.9 \\
HIV $_{\text {Zr6 }}$ & TM-B & env 2-3 & 753 & 0.9 & 3,616 & 0.9 \\
HIV $_{\text {Zr6 }}$ & TM-B & env 4 & 1,046 & 1.3 & 3,514 & 1.0 \\
None & TM-B & Yeast & 1,590 & & & 1.0
\end{tabular}

Specificity of HIV-specific T cell clones. Responses of CL 10 and CL 13 to a panel of recombinant HIV antigens were assessed. Stimulator cells were either HLA matched (TM-B) or mismatched (WG-B) with clones CL 10 and CL 13 at Class II HLA loci. SI, stimulation index. 
Table II. Reaction of Sera from HIV-1 Seropositive Individuals with Recombinant gp 120 Antigens from $H_{I} V_{S F 2}$ and $H I V_{Z r 6}$

\begin{tabular}{lllllll}
\hline & & \multicolumn{5}{c}{ OD of test sera } \\
\cline { 3 - 7 } Virus & Antigen & 1 & 2 & 3 & 4 & 5 \\
\hline HIV $_{\text {SF2 }}$ & env & 0.08 & 0.13 & 0.08 & $0.94^{*}$ & 0.11 \\
HIV $_{\text {SF2 }}$ & env 2-3 & 0.27 & $1.01^{*}$ & $1.09^{*}$ & $1.28^{*}$ & $1.21^{*}$ \\
HIV $_{\text {SF2 }}$ & env 4 & 0.15 & $1.05^{*}$ & $1.13^{*}$ & $1.20^{*}$ & $1.32^{*}$ \\
HIV $_{\text {Zr6 }}$ & env 2-3 & 0.20 & 0.37 & $1.00^{*}$ & $1.18^{*}$ & 0.30
\end{tabular}

Serum antibody responses to recombinant HIV antigens. An ELISA assay was used to assess reactivity of various human sera to the recombinant HIV antigens. The values shown for serum 1, the seronegative control, were obtained by averaging the results observed with seven HIV antibody-negative sera assayed in the same experiment. All values reported are the average of duplicate assay wells. Serum 2 is from the subject from whom the cloned cells were generated; sera 3 and 5 are from seropositive American donors; serum 4 is from an HIV seropositive African donor. Sera were considered positive (asterisks) when the OD reading was 2.5 times that of the seronegative control.

clones CL 10 and CL 13 to kill autologous EBV-transformed B cells that were infected with recombinant vaccinia virus that contains the gp 120 coding sequence of $\mathrm{HIV}_{\mathrm{SF} 2}$. Although gp 120 was expressed on the surface of these target cells (as as-

Table III. Production and Use of IL 2 by a CD4+ T Cell Clone

\begin{tabular}{|c|c|c|c|c|c|}
\hline \multicolumn{2}{|c|}{ Proliferation of cells } & \multirow[b]{2}{*}{ SI } & \multicolumn{2}{|c|}{ IL 2 activity in supernatants } & \multirow[b]{2}{*}{ SI } \\
\hline $\begin{array}{l}\mathrm{HIV}_{\mathrm{SF}} \\
\text { antigen }\end{array}$ & $\begin{array}{c}{\left[{ }^{3} \mathrm{H}\right] \text { Thymidine }} \\
\text { incorporated }\end{array}$ & & $\begin{array}{l}\text { Dilution of } \\
\text { supernatant }\end{array}$ & $\begin{array}{l}{\left[{ }^{3} \mathrm{H}\right] \text { Thymidine }} \\
\text { incorporated }\end{array}$ & \\
\hline \multirow[t]{3}{*}{ None } & 412 & - & $1: 2$ & 597 & 1.8 \\
\hline & & & $1: 4$ & 552 & 1.6 \\
\hline & & & $1: 8$ & 532 & 1.6 \\
\hline \multirow[t]{3}{*}{ env $2-3$} & 3,764 & 9.1 & $1: 2$ & 1,607 & 4.8 \\
\hline & & & $1: 4$ & 945 & 2.8 \\
\hline & & & $1: 8$ & 543 & 1.6 \\
\hline \multirow[t]{3}{*}{ env 1} & 3,194 & 7.8 & $1: 2$ & 1,576 & 4.7 \\
\hline & & & $1: 4$ & 829 & 2.5 \\
\hline & & & $1: 8$ & 582 & 1.7 \\
\hline \multirow[t]{3}{*}{ env 4} & 423 & 1.0 & $1: 2$ & 583 & 1.7 \\
\hline & & & $1: 4$ & 524 & 1.5 \\
\hline & & & $1: 8$ & 499 & 1.5 \\
\hline
\end{tabular}

Production and use of IL 2 by a CD4-positive T cell clone. Cloned CL 10 cells were tested for the ability to respond to various recombinant HIV $_{\text {SF2 }}$ antigens except that IL 2-free culture medium was used. After $72 \mathrm{~h}$ of incubation, $0.1 \mathrm{ml}$ of supernatant harvested from three replicate cultures established for each antigen was pooled and tested for IL 2 activity (see below). Each microtiter well then received $1 \mu \mathrm{Ci}$ of $\left[{ }^{3} \mathrm{H}\right]$ thymidine, and $12 \mathrm{~h}$ later the mean incorporation for triplicate wells was determined by liquid scintillation counting. Culture supernatants were assayed for their ability to induce proliferation of the IL 2-dependent cell line H-Y. Values shown are the mean counts per minute of $\left[{ }^{3} \mathrm{H}\right]$ thymidine incorporated by duplicate cultures receiving serial twofold dilutions of test supernatants. Stimulation indices (SI) were calculated by dividing these values by the mean counts per minute of $\left[{ }^{3} \mathrm{H}\right]$ thymidine incorporated by control cultures of $\mathrm{H}-\mathrm{Y}$ cells incubated in IL 2-free medium ( $300 \mathrm{cpm}$ in this experiment). sessed by syncytia formation with uninfected CD4+ T cells), no cytotoxic activity was detected (data not shown). Serum antibodies from this subject, in contrast to the two $T$ cell clones, did not react against the env 1 peptide of $\mathrm{HIV}_{\mathrm{SF} 2}$ in an ELISA assay (Table II). This result has been observed with sera from many other HIV-infected subjects (Steimer, K., unpublished observation). The finding suggests that the epitopes on gp 120 that are recognized by $T$ cells and by antibodies do not necessarily overlap. The reason for this discordant reactivity is not clear. Class II HLA-restricted T lymphocytes usually recognize antigen only after it has been internalized and processed by antigen-presenting cells; this process destroys the tertiary configuration of the molecule. As a result, $\mathrm{T}$ cells generally recognize epitopes that are defined by the primary amino acid sequence of the antigen, whereas antibodies react with conformational epitopes (21). Thus, improper folding of the env 1 peptide would be more likely to affect recognition by antibodies than $T$ cells. Alternatively, lack of glycosylation of the molecule, which was produced in a yeast vector, may have affected recognition by serum antibodies but not $T$ cells.

A selective defect in the in vitro proliferative response of peripheral blood lymphocytes to whole HIV and its envelope proteins (gp 41 and gp 120) has been observed, particularly in symptomatic individuals (22-24). This observation suggested that HIV-specific T helper cell activity is defective in infected individuals (24). The PBMC from the subject from whom the cloned cells were generated also failed to respond in a primary proliferation assay to the envelope peptides (data not shown). Nevertheless, the present results demonstrate for the first time that HIV type-specific T helper cells can be found in the peripheral blood of an infected individual. It is possible that the frequency of these IL 2-producing $T$ helper cells in the peripheral blood was low, and that they were selectively expanded in vitro by incubation with the envelope protein and IL 2. However, the role of HIV-specific T suppressor cells, defects in antigen presentation, or toxic effects of viral proteins, in contributing to this unresponsiveness have not yet been determined.

Our observations have implications for the development and use of an anti-HIV vaccine. First, potential vaccines that are able to stimulate and expand HIV-specific $T$ cells may be of value in halting the progression of disease, especially when used in conjunction with drugs that prevent replication of HIV. Second, because T cells but not antibodies reacted with the recombinant env 1 protein, separate epitopes must be recognized by humoral and cellular immune responses, and should be considered for use in a vaccine preparation. Finally, HIV-specific T cell clones such as the ones described here, when used in combination with synthetic peptides, can be useful reagents for defining the conserved and variable antigenic sites that should be included in an anti-HIV vaccine.

\section{Acknowledgments}

The authors would like to thank Philip J. Barr, Carlos George-Nascimento, Paul A. Luciw, Dino Dina, Peggy Wentworth, Elizabeth Sabin, and Alexander Gyenes for their contributions to the production, purification, and characterization of the antigens used in this work. Recombinant vaccinia viruses expressing the gp 120 envelope gene of HIV $_{\text {SF2 }}$ were kindly provided by Dr. E. Paoletti, Wadsworth Center for Laboratories and Research, Albany, NY. 
This research was supported by grants from the National Institute of Allergy and Infectious Diseases to J. A. Levy (RO1 AI-24499), and the Chiron Corporation (Small Business Innovative Research Grant 2R44AI22778), and a grant to J. A. Levy from the California State Universitywide Task Force on AIDS (R875F078). C. M. Walker is the recipient of a postdoctoral fellowship from the Medical Research Council of Canada.

\section{References}

1. Matthews, T. J., A. J. Langlois, W. G. Robey, N. T. Chang, R. C. Gallo, P. J. Fischinger, and D. P. Bolognesi. 1986. Restricted neutralization of divergent human $\mathrm{T}$ lymphotropic virus type III isolates by antibodies to the major envelope glycoprotein. Proc. Natl. Acad. Sci. USA. 83:9709-9713.

2. Walker, B. D., S. Chakrabarti, B. Moss, T. J. Paradis, T. Flynn, A. G. Durno, R. S. Blumberg, J. C. Kaplan, M. S. Hirsch, and R. T. Schooley. 1987. HIV-specific cytotoxic T lymphocytes in seropositive individuals. Nature (Lond.). 328:345-348.

3. Plata, F., B. Autran, L. Pedroza Martins, S. Wain-Hobson, M. Raphael, C. Mayaud, M. Denis, J. M. Guillon, and P. Debre. 1987. AIDS virus-specific cytotoxic T lymphocytes in lung disorders. Nature (Lond.). 328:348-351.

4. Hahn, B. H., M. A. Gonda, G. M. Shaw, M. Popovic, J. A. Hoxie, R. C. Gallo, and F. Wong-Staal. 1985. Genomic diversity of the acquired immunodeficiency syndrome virus HTLV-III: different viruses exhibit greatest divergence in their envelope regions. Proc. Natl. Acad. Sci. USA. 82:4813-4817.

5. Starcich, B. R., B. H. Hahn, G. M. Shaw, P. D. McNeely, S. Modrow, H. Wolf, E. S. Parks, W. P. Parks, S. F. Josephs, R. C. Gallo, and $F$. Wong-Staal. 1986. Identification and characterization of conserved and variable regions in the envelope gene of HTLV/LAV, the retrovirus of AIDS. Cell. 45:637-648.

6. Cease, K. B., H. Margalit, J. L. Cornette, S. D. Putney, W. G. Robey, C. Ouyang, S. C. Streicher, P. J. Fishinger, R. C. Gallo, C. DeLisi, and J. A. Berzofsky. 1987. Helper T cell antigenic site identification in the acquired immunodeficiency syndrome virus gp 120 envelope protein and induction of immunity in mice to the native protein using a 16-residue synthetic peptide. Proc. Natl. Acad. Sci. USA. 84:4249-4253.

7. Kaplan, D. R., R. Griffith, V. L. Braciale, and T. J. Braciale. 1984. Influenza virus: specific human cytotoxic T cell clones: Heterogeneity in antigen specificity and restriction by class II MHC products. Cell. Immunol. 88:193-206.

8. Yasukawa, M., and J. M. Zarling. 1984. Human cytotoxic T cell clones directed against herpes simplex virus-infected cells II. Bifunctional clone for cytotoxic and virus-induced proliferative activities exhibit herpes simplex type 1 and 2 specific or type common reactivities. J. Immunol. 133:2736-2742.

9. Barr, P. J., K. S. Steimer, E. A. Sabin, D. Parkes, C. George-Nascimento, J. C. Stephans, M. A. Powers, A. Gyenes, G. A. Van Nest, E. T. Miller, K. W. Higgins, and P. A. Luciw. 1987. Antigenicity and immunogenicity of domains of the human immunodeficiency virus (HIV) envelope polypeptide expressed in the yeast Saccharomyces cerevisiae. Vaccine. 5:90-101.

10. Levy, J. A., A. D. Hoffman, S. M. Kramer, J. A. Landis, J. M. Shimabukuro and L. S. Oshiro. 1984. Isolation of lymphocytopathic retroviruses from San Francisco patients with AIDS. Science (Wash. DC). 225:840-842.

11. Srinivasan, A., R. Anand, D. York, E. Ranganathan, P. Feor- ino, G. Schochetman, J. Curran, V. S. Kalyanaraman, P. A. Luciw, and R. Sanchez-Pescador. 1987. Molecular characterization of human immunodeficiency virus from Zaire: Nucleotide sequence analysis identifies conserved and variable domains in the envelope gene. Gene (Amst.). 52:71-82.

12. Steimer, K. S., J. P. Puma, M. D. Power, M. A. Powers, C. George-Nascimento, J. C. Stephens, J. A. Levy, R. Sanchez-Pescador, P. A. Luciw, P. J. Barr, and R. A. Hallewell. 1986. Differential antibody responses of individuals infected with AIDS-associated retroviruses surveyed using the viral core antigen $\mathrm{p} 25^{\mathrm{gag}}$ expressed in bacteria. Virology. 150:283-290.

13. Evans, L., C. Maragos, and J. T. May. 1984. Human lymphoblastoid cell lines established from peripheral blood lymphocytes secreting immunoglobulins directed against herpes simplex virus. Immunol. Lett. 8:39-42.

14. Walker, C. M., P. Paetkau, W. E. Rawls, and K. L. Rosenthal. 1985. Abrogation of anti-pichinde virus cytotoxic $\mathrm{T}$ cell memory by cyclophosphamide and restoration by coinfection or interleukin 2 . 1985. J. Immunol. 135:1401-1407.

15. Steimer, K. S., K. W. Higgins, M. A. Powers, J. C. Stephans, A. Gyenes, C. George-Nascimento, P. A. Luciw, P. J. Barr, R. A. Hallewell, and R. Sanchez-Pescador. 1986. Recombinant polypeptide from the endonuclease region of the acquired immune deficiency syndrome retrovirus polymerase (pol) gene detects serum antibodies in most infected individuals. J. Virol. 58:9-16.

16. Kansas, G. S., G. S. Wood, D. M. Fishwild, and E. G. Engelman. 1985. Functional characterization of human T lymphocyte subsets distinguished by monoclonal anti-Leu-8. J. Immunol. 134:29953002.

17. Swain, S. L. 1983. T cell subsets and the recognition of MHC class. Immunol. Rev. 74:129-138.

18. Smith, K. A. 1980. T-cell growth factor. Immunol. Rev. 51:337-357.

19. Zubler, R. H., J. W. Lowenthal, F. Erard, N. Hashimoto, R. Devos, and H. MacDonald. 1984. Activated B cells express receptors for, and proliferate in response to, pure interleukin 2. J. Exp. Med. 160:1170-1183.

20. Zarling, J. M., J. W. Eichberg, P. A. Moran, J. McClure, P. Sridhar, and S.-L. Hu. 1987. Proliferative and cytotoxic T cells to AIDS virus glycoproteins in chimpanzees immunized with a recombinant vaccinia virus expressing AIDS virus envelope glycoproteins. $J$. Immunol. 139:988-990.

21. Livingstone, A. M., and C. G. Fathman. 1987. The structure of T-cell epitopes. Annu. Rev. Immunol. 5:477-501.

22. Wahren, B., L. Morfeldt-Mansson, G. Biberfeld, L. Moberg, P. Ljungman, S. Nordlund, U. Bredberg-Raden, A. Werner, J. Lower, R. Kurth. 1986. Impaired specific cellular response to HTLV-III before other immune defects in patients with HTLV-III infection. 1986. $N$. Engl. J. Med. 315:393-394.

23. Krohn, K., W. G. Robey, S. Putney, L. Arthur, P. Nara, P. Fischinger, R. C. Gallo, F. Wong-Staal, and A. Ranki. 1987. Specific cellular immune response and neutralizing antibodies in goats immunized with native or recombinant envelope proteins derived from human T-lymphotropic virus type $\mathrm{III}_{B}$ and in human immunodeficiency virus-infected men. Proc. Natl. Acad. Sci. USA. 84:4994-4998.

24. Wahren, B., L. Morfeldt-Mansson, G. Biberfeld, L. Moberg, A Sonnerborg, P. Ljungman, A. Werner, R. Kurth, R. Gallo, and D. Bolognesi. 1987. Characteristics of the specific cell-mediated immune response in human immunodeficiency virus infection. J. Virol. 61:2017-2033. 